\title{
IMPACT OF ARBUSCULAR MYCORRHIZAL FUNGI AND PSEUDOMONAS FLUORESCENS ON GROWTH, PHYSIOLOGICAL PARAMETERS AND ESSENTIAL OIL CONTENT IN OCIMUM BASILICUM L.
}

\author{
ESHA JANGRA ${ }^{1}$, KULDEEP YADAV ${ }^{2}$, and ASHOK AGGARWAL ${ }^{1, *}$ \\ ${ }^{1}$ Department of Botany, Kurukshetra University, Haryana-136119, India \\ 2 Department of Botany, Gandhi Memorial National College, Ambala Cantt., Haryana-133001, India \\ *Corresponding author: aggarwal_vibha@rediffmail.com
}

\begin{abstract}
A pot experiment was performed to see the interactive potential of Glomus mosseae and Acaulospora laevis alone or in combination with Pseudomonas fluorescens on Ocimum basilicum L. under glass house conditions. Various morphological and physiological parameters were measured after 120 days. Although, all co-inoculation treatments showed beneficial effects but $G$. mosseae is found to be the most compatible strain found in the rhizosphere of basil plant. G. mosseae alone or in combination with other bioinoculants showed maximum increase in all the different parameters studied (plant height, fresh weight, dry weight, leaf number, inflorescence height, root and shoot phosphorus, acidic and alkaline phosphatase and oil content). The overall results demonstrate that the co-inoculation of $P$. fluorescens with AM fungi promotes higher mycorrhizal colonization enhancing nutrient acquisition especially phosphorus $(P)$, producing plant growth hormones resulting in improvement of rhizospheric condition of soil, altering the physiological and biochemical properties of sweet basil.
\end{abstract}

Keywords: Acaulospora laevis; essential oil; Glomus mosseae; Ocimum basilicum; Pseudomonas fluorescens

\section{Introduction}

Ocimum basilicum L. (family: Lamiaceae) known as sweet basil, is an important annual herb cultivated all over the temperate regions. Basil is a rich source of phenolic, antioxidant compounds, flavonoids and essential oils. It has been traditionally used for the treatment of many ailments, such as headaches, coughs and diarrhea (Phippen and Simon 1998; Javanmardi et al. 2002). The essential oils mainly found in leaves are volatile and mostly consisting of monoterpenes and sesquiterpenes are commonly utilized in the spice industry (Werker et al. 1993)

Plants generally take nutrients from the soil by simply root soil interaction with the help of various microorganisms. The interaction between the roots of the plant and the soil microorganisms help plants to acquire necessary mineral nutrients from the soil (Prasad et al. 2012; Yadav et al. 2015). Among the different macronutrients, Phosphorus (P) is the most frequent essential mineral occurs in immobilize form in the soil. In the past few decades, Arbuscular Mycorrhizal Fungi (AMF) has emerged as potential biofertilizers and environmentally friendly alternative to chemical fertilizers (Cagras et al. 2000). Plants in association with AM fungi interact to perform the efficient solubilization of these mineral elements in the rhizosphere. During this process, the plant roots intercept with the fungal hyphae establishing a mutual symbiotic association between the roots of the plants and AMF which is very useful in exploration of the larger soil volume thereby making 'positionally unavailable' nutrients 'available' by increasing the surface area for absorption (Tinker and Gildon 1983). On the other hand, the uncontrolled and indiscriminate use of chemical fertilizers causes adverse effects on soil health and environment also.

PGPR (Plant Growth Promoting Rhizobacterium) are naturally occurring soil microorganisms that colonize roots and stimulate plant growth. Such bacteria are applied to a wide range of agricultural crops for the purpose of growth enhancement and yield (Raj et al. 2003). Plant growth promotion in plants as a result of rhizobacterium soil inoculation may increase the production of growth hormones and solubilization of phosphates (Kloepper et al. 1993).

Keeping in view of above information, the present study was carried out to assess the consequent effect of dominant AM fungi (Glomus mosseae and Acaulospora laevis) alone or in various combinations with $P$. fluorescens to find out the best combination having the maximum capability of increasing plant growth and oil content in basil plant.

\section{Materials and Methods}

\section{Mass multiplication of bioinoculants}

The two dominant AM species (Glomus mosseae and Acaulospora laevis) were isolated from the rhizospheric soil of Ocimum basilicum L. grown in Botanical Garden of Botany Department, Kurukshetra University by using Wet Sieving and Decanting Technique of Gerdemann and Nicolson (1963) and identified using the key of Schenck and Perez (1990). The starter inoculum for each species were multiplied by "Funnel Technique" of Menge and Timmer (1982) - see also Sharma et al. (2017). The AM species 
were multiplied with maize as host for three months. Pseudomonas fluorescens (MTCC NO. 103) was procured from Institute of Microbial Technology (IMTECH), Chandigarh, India and cultured in a Nutrient Broth Medium incubated at $32{ }^{\circ} \mathrm{C}$ for 48 hours to obtain a concentration of $1 \times 10^{9}$ colony forming units $(\mathrm{cfu}) \mathrm{ml}^{-1}$.

\section{Experimental site and setup}

The experiment was set up in the polyhouse, Botany Department, Kurukshetra University, Kurukshetra, Haryana during June to September, 2016. The soil used in the experiment consisted of Clay $-3.78 \%$, Silt $-20.8 \%$, Sand - 74.5\%, EC - $0.26 \mathrm{dS} / \mathrm{m}$, Organic Carbon - 0.40\%, total $\mathrm{N}-0.042 \%, \mathrm{P}-7.30 \mathrm{~kg}^{-1}$ acre, $\mathrm{K}-88 \mathrm{~kg}^{-1}$ acre and $\mathrm{S}-14.80 \mathrm{ppm}$. The experiment was laid out in a randomized complete block design with five replicates per treatment. Top soil $(0-30 \mathrm{~cm})$ was collected and sieved through $2 \mathrm{~mm}$ sieve, mixed with sand, soil in the ratio $1: 3$ and sterilized in autoclave for 20 minutes at $121^{\circ} \mathrm{C}$ at 15 psi. Earthen pots $(25 \times 25 \mathrm{~cm})$ were selected having capacity of $2 \mathrm{~kg}$ soil. For AM treatment $10 \%(\mathrm{w} / \mathrm{w})$ of soil of the selected AM inoculum having 845 AM spores approximately and $200 \mathrm{~g}$ of soil having chopped AM colonized pieces of trapped host barley with the infection level of about $90-95 \%$ were added. Before sowing, the roots of the seedlings were dipped in the nutrient broth having $P$. fluorescence. The experiment was set up with the following treatments:

1) Control (C)

2) Glomus mosseae (G)

3) Acaulospora laevis (A)

4) Pseudomonas fluorescence (P)

5) Glomus mosseae + Acaulospora laevis $(\mathrm{G}+\mathrm{A})$

6) Acaulospora laevis + Pseudomonas fluorescence $(\mathrm{A}+\mathrm{P})$

7) Glomus mosseae + Pseudomonas fluorescence $(\mathrm{G}+\mathrm{P})$

8) Glomus mosseae + Acaulospora laevis + Pseudomonas fluorescence $(\mathrm{G}+\mathrm{A}+\mathrm{P})$

In the control set no inoculum was added. Plants were watered regularly to maintain humidity. Hoagland $\mathrm{Nu}-$ trient solution without phosphorus (100 ml/pot) was added to each pot after regular interval of 20 days. Each treatment was replicated five times. After 120 days, five plants from each treatment were analyzed for the various morphological and physiological parameters.

\section{Essential oil isolation}

After the flowering, leaves and shoots of basil were harvested and essential oil was extracted by hydro distillation of one-liter water in a Clevenger apparatus for eight hours (Rasooli and Mirmostafa 2003). The essential oil was collected and stored in glass vials prior to determination of chemical compounds.

\section{Harvest and analysis}

After 120 days, the plants were uprooted and analyzed for various morphological and physiological parameters. Shoot length $(\mathrm{cm})$ were analyzed. Percentage root col- onization was assessed by Rapid Clearing and Staining Technique of Phillips and Hayman (1970). AM spores were isolated by Wet Sieving and Decanting Technique of Gerdemann and Nicolson (1963). Alkaline and acidic phosphatase of fresh roots was estimated by Tabatabai and Bremner (1969). Shoot and root phosphorus were determined by vanado-molybdo-phosphoric acid yellow colour method (1973). Total chlorophyll content was estimated by using Arnon's method (1949) using $80 \%$ acetone as solvent.

\section{Statistical analysis}

The experimental data was analyzed using analysis of Variance (ANOVA), followed by post hoc test using the Statistical package for Social Sciences (ver. 16). Means were then ranked at $\leq 0.05$ level of significance using Duncan's Multiple Range Test (DMRT) for comparison.

\section{Results and Discussion}

Significant variation was observed in growth parameters and essential oil content as influenced by different bioinoculant treatments. Results showed that mycorrhizal plants showed significant increase in plant height, shoot and root fresh and dry weight, number of leaves, inflorescence length (Table 1). After 120 days of inoculation highest mycorrhizal colonization and AM spore number was observed in $A+G$ followed by $G+A+P$ (Table 2). Plants inoculated with the different bioinoculants showed higher degree of phosphorus acquisition as compared to control ones (Table 3). Phosphorus content in non-mycorrhizal treatments was lower than that of mycorrhizal treatment. The higher nutrient uptake in mycorrhizal basil plants might be attributed to the combination of fungal external mycelia, which explore a large volume of soil and absorb more nutrients. It was also observed that mycorrhizal treated plants have better root architecture which helps the plants in better uptake of Phosphorus. The main explanation is that AMF developed an extra metrical mycelium, which increased the root phosphate absorbing sites by producing phosphatase enzyme (Bolan 1991). The increase in root phosphorus activity in AM treated plants may be due to higher capacity of AMF hyphae to explore more soil volume beyond the depletion zone and thus triggering the $\mathrm{P}$ transport from soil to plant roots.

In the present investigation the effect of AM Fungi on the rhizospheric bacteria was caused by a direct interaction between the fungal mycelia of Glomus mosseae and the Pseudomonas fluorescens. The nutrient status of plant also influences root exudates composition (Lipton et al. 1987), because of which the rhizospheric population of Pseudomonas fluorescens increases which in turn helps in the better absorption of nutrient by exploring phosphorus rich soil areas away from the root surface. In the present study, AM colonization to basil 
Table 1 Interaction of AM Fungi and P. fluorescens on different growth parameters of Ocimum basilicum L. after 120 days.

\begin{tabular}{|c|c|c|c|c|c|c|c|}
\hline Treatments & $\begin{array}{l}\text { Plant height } \\
\quad(\mathrm{cm})\end{array}$ & $\begin{array}{l}\text { Fresh shoot } \\
\text { weight (g) }\end{array}$ & $\begin{array}{l}\text { Dry shoot } \\
\text { weight (g) }\end{array}$ & $\begin{array}{l}\text { Fresh root } \\
\text { weight (g) }\end{array}$ & $\begin{array}{l}\text { Dry root } \\
\text { weight (g) }\end{array}$ & $\begin{array}{c}\text { Leaf } \\
\text { number/plant }\end{array}$ & $\begin{array}{c}\text { Inflorescence } \\
\text { Height (cm) }\end{array}$ \\
\hline Control & $29.20^{9}$ & $6.28^{h}$ & $1.48^{\mathrm{h}}$ & $5.20^{\mathrm{h}}$ & $0.62^{9}$ & $51.00^{\mathrm{e}}$ & $7.0^{\mathrm{e}}$ \\
\hline A. laevis & $37.60^{f}$ & 12.809 & $2.06^{9}$ & $7.28^{9}$ & $0.79^{f}$ & $67.00^{d}$ & $7.6^{d}$ \\
\hline G. mosseae & $52.64^{b}$ & $20.90^{b}$ & $4.09^{b}$ & $10.98^{c}$ & $1.22^{c}$ & $86.00^{\mathrm{ab}}$ & $8.6^{b}$ \\
\hline P. fluorescens & $44.80^{d}$ & $16.40^{d}$ & $3.02^{d}$ & $10.22^{d}$ & $0.98^{d}$ & $81.00^{b}$ & $8.2^{c}$ \\
\hline$A+G$ & $41.60^{e}$ & $13.98^{\mathrm{e}}$ & $2.68^{e}$ & $8.78^{e}$ & $0.86^{\mathrm{e}}$ & $74.00^{c}$ & $7.8^{\mathrm{cd}}$ \\
\hline $\mathbf{G}+\mathbf{P}$ & $54.20^{\mathrm{a}}$ & $21.40^{\mathrm{a}}$ & $4.25^{\mathrm{a}}$ & $12.02^{\mathrm{a}}$ & $1.47^{\mathrm{a}}$ & $90.00^{a}$ & $9.0^{\mathrm{a}}$ \\
\hline$A+P$ & $38.20^{f}$ & $13.22^{f}$ & $2.24^{f}$ & $7.46^{f}$ & $0.82^{\mathrm{ef}}$ & $71.00^{c d}$ & $8.0^{\mathrm{cd}}$ \\
\hline $\mathbf{G}+\mathbf{A}+\mathbf{P}$ & $48.20^{c}$ & $17.20^{c}$ & $3.808^{c}$ & $11.88^{b}$ & $1.36^{b}$ & $88.00^{a}$ & $9.2^{\mathrm{a}}$ \\
\hline L.S.D. $(P \leq 0.05)$ & 0.725 & 0.225 & 0.0615 & 0.085 & 0.0515 & 5.985 & 0.275 \\
\hline ANOVA $\left(F_{7,16}\right)$ & 986.503 & 3.572 & 1.974 & 5.470 & 222.16 & 27.822 & 16.766 \\
\hline
\end{tabular}

G - Glomus mosseae, A - Acaulospora laevis, P-Pseudomonas fluorescens

\pm Standard deviation

* The mean difference is significant at 0.5 levels. Mean value followed by different alphabet/s within a column do not differ significantly over one other at $\mathrm{P}<0.05$ (Duncan's Multiple Range Test).

Table 2 Effect of AM Fungi and P. fluorescence on mycorrhization and oil content (\%) of Ocimum basilicum L. after 120 days.

\begin{tabular}{|c|c|c|c|}
\hline Treatments & AMF root colonization (\%) & AM Spore number per $\mathbf{2 0} \mathrm{g}$ of soil & Essential Oil content (\%) \\
\hline Control & $0^{e}$ & $0^{e}$ & $0.50^{f}$ \\
\hline A. laevis & $63^{c}$ & $145^{d}$ & $0.64 \mathrm{ef}^{\mathrm{s}}$ \\
\hline G. mosseae & $76^{b}$ & $200^{b}$ & $1.00^{c}$ \\
\hline P. fluorescens & $0^{e}$ & $0^{e}$ & $0.74^{\mathrm{de}}$ \\
\hline $\mathbf{A}+\mathbf{G}$ & $85^{a}$ & $214^{a}$ & $1.05^{b c}$ \\
\hline $\mathbf{G}+\mathbf{P}$ & $55^{d}$ & $185^{c}$ & $1.20^{\mathrm{ab}}$ \\
\hline$A+P$ & $63.8^{c}$ & $176^{c}$ & $0.88^{c d}$ \\
\hline $\mathbf{G}+\mathbf{A}+\mathbf{P}$ & $80^{\mathrm{ab}}$ & $212^{\mathrm{a}}$ & $1.25^{\mathrm{a}}$ \\
\hline L.S.D. $(P \leq 0.05)$ & 7.655 & 10.515 & 0.195 \\
\hline ANOVA $\left(F_{7,16}\right)$ & 151.136 & 543.288 & 7.694 \\
\hline
\end{tabular}

G - Glomus mosseae, A - Acaulospora laevis, P - Pseudomonas fluorescens

\pm Standard deviation.

* The mean difference is significant at 0.5 levels. Mean value followed by different alphabet/s within a column do not differ significantly over one other at $\mathrm{P}<0.05$ (Duncan's Multiple Range Test).

Table 3 Effect of AM Fungi and P. fluorescence on different physiological parameters of Ocimum basilicum L. after 120 days.

\begin{tabular}{|c|c|c|c|c|c|c|c|c|}
\hline \multirow{2}{*}{ Treatments } & \multicolumn{3}{|c|}{$\begin{array}{l}\text { Chlorophyll Content } \\
\text { (mg/g FW) }\end{array}$} & \multirow{2}{*}{$\begin{array}{l}\text { Carotenoid } \\
\text { (mg/g FW) }\end{array}$} & \multicolumn{2}{|c|}{$\begin{array}{l}\text { Phosphatase activity } \\
\text { (IU/G FW) }\end{array}$} & \multicolumn{2}{|c|}{$\begin{array}{l}\text { Phosphorus } \\
\text { Content (P) }\end{array}$} \\
\hline & Chlorophyll a & Chlorophyll b & $\begin{array}{c}\text { Total } \\
\text { Chlorophyll }\end{array}$ & & $\begin{array}{c}\text { Acidic } \\
\text { phosphatase }\end{array}$ & $\begin{array}{c}\text { Alkaline } \\
\text { phosphatase }\end{array}$ & Shoot P & Root P \\
\hline Control & $0.368^{f}$ & $0.113^{f}$ & $0.481^{f}$ & $0.186 \mathrm{e}$ & $0.057 \mathrm{e}$ & $0.09^{d}$ & $0.43^{f}$ & $0.66^{f}$ \\
\hline A. Iaevis & $0.878^{b c}$ & $0.284^{c}$ & $1.162^{b c}$ & $0.391^{b}$ & $0.139 \mathrm{de}$ & $0.039 d$ & $0.67 \mathrm{e}$ & $0.75^{\mathrm{ef}}$ \\
\hline G. mosseae & $0.815^{\mathrm{de}}$ & $0.268^{\mathrm{cd}}$ & $1.083^{d}$ & $0.355^{c}$ & $0.18^{c d}$ & $0.221^{b}$ & $0.87^{c d}$ & $1.96^{\mathrm{a}}$ \\
\hline P. fluorescens & $0.782^{\mathrm{e}}$ & $0.243^{d}$ & $1.025^{\mathrm{e}}$ & $0.32^{d}$ & $0.09^{d e}$ & $0.012^{d}$ & $0.46^{f}$ & $0.89^{\mathrm{de}}$ \\
\hline$A+G$ & $0.887^{b}$ & $0.324^{b}$ & $1.211^{\mathrm{b}}$ & $0.394^{b}$ & $0.256^{b c}$ & $0.263^{b}$ & $1.07^{b}$ & $1.43^{b}$ \\
\hline $\mathbf{G}+\mathbf{P}$ & $0.837 \mathrm{~cd}$ & $0.273^{\mathrm{cd}}$ & $1.11^{c d}$ & $0.347^{b}$ & $0.135^{\mathrm{de}}$ & $0.128^{c}$ & $0.97^{b c}$ & $1.13^{c}$ \\
\hline$A+P$ & $0.817^{\text {de }}$ & $0.168^{e}$ & $0.985^{e}$ & $0.387^{b}$ & 0.097 de & $0.054^{\mathrm{cd}}$ & $0.71^{\mathrm{de}}$ & $1^{c d}$ \\
\hline$G+A+P$ & $0.956^{a}$ & $0.356^{a}$ & $1.312^{\mathrm{a}}$ & $0.46^{\mathrm{a}}$ & $0.328^{a}$ & $0.381^{a}$ & $1.89^{\mathrm{a}}$ & $2.09^{a}$ \\
\hline L.S.D. $(P \leq 0.05)$ & .0475 & 0.0315 & 0.0555 & 0.0265 & 0.082 & 0.03 & 0.1639 & 0.09 \\
\hline ANOVA $\left(F_{7,16}\right)$ & 81.727 & 50.550 & 126.235 & 44.751 & 6.308 & 18.043 & 38.713 & 50.608 \\
\hline
\end{tabular}

G-Glomus mosseae, A - Acaulospora laevis, P- Pseudomonas fluorescens

\pm Standard deviation,

* The mean difference is significant at 0.5 levels. Mean value followed by different alphabet/s within a column do not differ significantly over one other at $\mathrm{P}<0.05$ (Duncan's Multiple Range Test). 
plant showed positive effect on the plant growth and it might have resulted in increased bacterial activity thereby absorbing more nutrients from the soil. Yadav et al. (2015) and Prasad et al. (2012) also noticed growth stimulation effects by using PGPR strains. This specificity appears to be related to different composition of rhizosphere exudates secreted by basil plant affecting the levels of colonization and subsequently the efficacy of the Pseudomonas fluorescens or to the specific compounds present in the exudates that may stimulate the synthesis of secondary metabolites in the bacteria used in the plant growth (Mishra et al. 2017).

Essential oils are volatile lipophilic mixture of compounds obtained from plants, mostly consisting of monoterpenes, phenyl propenoids and sesquiterpenes. The biosynthesis of essential oil depends upon the availability of phosphorus content in the plant. In the present investigation, it was found that the essential oil content significantly increased in mycorrhizal treated plant regardless of the AM fungal species. However, plants inoculated with Glomus mosseae showed significant increase in essential oil in comparison to Acaulospora laevis. There was relatively difference in the percent oil content in the leaves of different bioinoculant treated plants (Table 2). Positive significant relationships were found in inoculated plants between essential oil percent and AM root colonization, AM spore number and biomass. The increases of essential oil content have been linked to greater plant biomass because of mycorrhization (Copetta et al. 2006). When plant growth increases, more photosynthates especially chlorophyll content are produced resulting in higher allocation of fixed carbon source. G. mosseae is the most compatible strain found in the rhizosphere of basil plant because where ever G. mosseae is present whether alone or in combination with other bioinoculants the growth and essential oil contents were significantly higher. There are many processes that contribute to improved $\mathrm{P}$ acquisition by mycorrhizal plants. These include better root architecture for more absorption of nutrients and through solubilization of phosphorus by phosphatases. In our results, mycorrhizal treated plants showed more acidic and alkaline phosphate activity which may be due to increased exploration of soil particles by AM hyphae. Similar results were also reported for Coriandrum sativum by Kapoor et al. (2002), for Citrus jambhiri by Nemec and Lund (1990), for Mentha arvensis by Freitas et al. (2004), Khaliq and Janardhan (1997) respectively. The increased essential oil production is result of the increased production of fresh shoot foliage (Subrahmanyam et al. 1992). Moreover, Copetta et al. (2006) observed that Glomus rosea increased essential oil yield was associated with large number of peltate glandular trichomes in the leaves of Ocimum basilicum. They further suggested that the greater number of trichomes could be related to alterations in the phytohormonal profile induced by AM fungi.

\section{Conclusions}

The results of this study clearly reveal that the inoculation with AM fungi and other bioinoculants is more effective in increasing of growth, biochemical attributes and oil content of basil plant. This increase could be attributed to the increased surface area of roots, better water absorption, enhanced uptake of nutrients and secretion of some enzymes by inoculated microorganisms. G. mosseae is the most compatible strain found in the rhizosphere of basil plant because where ever G. mosseae is present whether alone or in combination with other bioinoculants the growth and essential oil contents were significantly higher. This combination can be tested further in the field conditions and can be recommended to farmers after proper confirmation.

\section{Acknowledgements}

The authors are thankful to Kurukshetra University, Kurukshetra, India for providing laboratory facilities. The financial assistance received from Kurukshetra University to Esha in the form of URS is also acknowledged.

\section{REFERENCES}

Arnon DI (1949) Copper enzyme in isolated chloroplasts polyphenol oxidase in Beta vulgaris. Plant Physiol 24: 1-5.

Bolan NS (1991) A critical review on the role of mycorrhizal fungi in the uptake of phosphorus by plants. Plant Soil 134: 189-207.

Cagras S, Sari N, Ortas I (2000) The effects of vesicular arbuscular mycorrhizae on the plant growth and nutrient uptake of $\mathrm{cu}$ cumber. Turk J Agric Forest 24: 571-578.

Copetta A, Lingua G, Berta G (2006) Effects of three AM fungi on growth, distribution of glandular hairs, and essential oil production in Ocimum basilicum L. var. Genovese. Mycorrhiza 16: 485-494.

Freitas MSM, Martins MA, Vieira IJC (2004) Yield and quality of essential oils of Mentha arvensis in response to inoculation with arbuscular mycorrhizal fungi. Pesq Agropec Bras 39: 887-894.

Gerdemann JW, Nicolson YH (1963). Spores of mycorrhizae Endogone species extracted from soil by wet sieving and decanting. Trans Br Mycol Soc 46: 235-244.

Javanmardi J, Khalighi A, Kashi A, Bais HP, Vivanco JM (2002) Chemical characterization of basil (Ocimum basilicum L.) found in local accessions and used in traditional medicines in Iran. J Agric Food Chem 50: 5878-5883.

Kapoor R, Giri B, Mukerji KG (2002) Mycorrhization of coriander (Coriandrum sativum L.) to enhance the concentration and quality of essential oil. J Sci Food Agric 82: 339-342.

Khaliq A, Janardhanan KK (1997) Influence of vesicular arbuscular mycorrhizal fungi on the productivity of cultivated mints. J Med Arom Plant Sci 19: 7-10.

Kloepper JW, Tuzun S, Liu L, Wei G (1993) Plant growth-promoting rhizobacteria as inducers of systemic disease resistance. In: Lumsden RD, Waughn JL (eds) Pest management: biologically based technologies. American Chemical Society Books, Washington, DC, pp 156-165. 
Lipton DS, Blanchar RW, Blevins DG (1987) Citrate, malate, and succinate concentration in exudates from P-sufficient and P-stressed Medicago sativa L. seedlings. Plant Physiol 85: 315317.

Menge JA, Timmer LM (1982) Procedure for inoculation of plants with VAM in the laboratory, greenhouse and field. In: Schenck NC (ed) Methods and Principles of Mycorrhizal Research, American Phytopathological Society, St. Paul, pp 59-68.

Mishra J, Singh R, Arora NK (2017) Plant Growth-Promoting Microbes: Diverse Roles in Agriculture and Environmental Sustainability. Probiotics and Plant Health, pp 71-111.

Nemec S, Lund E (1990) Leaf volatiles of mycorrhizal and nonmycorrhizal Citrus jambhiri Lush. J Essent Oil Res 2: 287-297.

Phillips JM, Hayman DS (1970) Improved procedures for clearing roots and staining parasitic and vesicular-arbuscular mycorrhizal fungi for rapid assessment of infection. Trans Br Mycol Soc 55: $158-161$.

Phippen WB, Simon JE (1998) Anthocyanins in basil (Ocimum basilicum L.). J Agric Food Chem 46: 1734-1738.

Prasad K, Aggarwal A, Yadav K, Tanwar A (2012) Impact of different levels of superphosphate using arbuscular mycorrhizal fungi and Pseudomonas fluorescens on Chrysanthemum indicum L. J Soil Sci Plant Nutr 12: 451-462.

Raj SN, Deepak SA, Basavaraju P, Shetty HS, Reddy MS, Kloepper JW (2003) Comparative performance of formulations of plant growth promoting rhizobacteria in growth promotion and suppression of downy mildew in pearl millet. Crop Protection 22: 579-588.
Rasooli I, Mirmostafa SA (2003) Bacterial susceptibility to and chemical composition of essential oils from Thymus kotschyanus and Thymus persicus. J Agric Food Chem 51: 2200-2205.

Schenck NC, Perez Y (1990) Manual for the identification of VA mycorrhizal fungi. 3rd ed, Synergistic Publication, Gainesville, USA.

Sharma N, Aggarwal A, Yadav K (2017) Arbuscular mycorrhizal fungi enhance growth, physiological parameters and yield of salt stressed Phaseolus mungo (L.) Hepper. Eur J Environ Sci 7: 5-13.

Subrahmanyam K, Chattopadhyay A, Nair AK, Singh DV (1992) Yield response and iron status of Japanese mint as influenced by soil and foliar applied iron. Fertilizer Res 31: 1-4.

Tabatabai MA, Bremner JM (1969) Use of p-nitrophenyl phosphate for assay of soil phosphatase activity. Soil Biol Biochem 1: 301-307.

Tinker PB, Gildon A (1983) Mycorrhizal fungi and ion uptake. In: Metals and Micronutrients. Uptake and utilization of metals by plants. In: Robb DA, Pierpoint WS (eds) Academic Press, London, pp 21-32.

Werker E, Putievsky E, Ravid U, Dudai N, Katzir I (1993) Glandular hairs and essential oil in developing leaves of Ocimum basilicum L. (Lamiaceae). Ann Bot 71: 43-50.

Yadav A, Yadav K, Aggarwal A (2015) Impact of Arbuscular Mycorrhizal Fungi with Trichoderma viride and Pseudomonas fluorescens on Growth, Yield and Oil Content in Helianthus annuus L. J Essent Oil Bearing Plant 18: 444-454. 